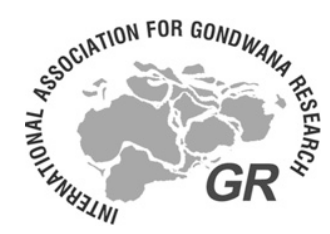

www.elsevier.com/locate/gr

\title{
Tonian rift-related, A-type continental plutonism in the Araçuaí Orogen, eastern Brazil: New evidence for the breakup stage of the São Francisco-Congo Paleocontinent
}

\author{
L.C. da Silva ${ }^{a, b, *}$, A.C. Pedrosa-Soares ${ }^{b, c}$, L.R., Teixeira ${ }^{a}$, R. Armstrong ${ }^{\text {d }}$ \\ ${ }^{\text {a } C P R M}$ - Serviço Geológico do Brasil - SGAN 603, Bloco J, Brasília, DF, Brazil \\ ${ }^{\mathrm{b}}$ Conselho Nacional de Desenvolvimento Científico e Tecnológico-CNPq, Brazil \\ ${ }^{\mathrm{c}}$ CPMTC-IGC-UFMG, Av. Antônio Carlos, 6627, Belo Horizonte 31270-901 MG, Brazil \\ ${ }^{\mathrm{d}}$ Research School of Earth Sciences, Mills Road, The Australian National University/ANU, Canberra 0200 A.C.T., Australia
}

Received 27 July 2005; received in revised form 30 May 2007; accepted 8 June 2007

Available online 16 June 2007

\begin{abstract}
Zircon U-Pb SHRIMP, petrographical and geochemical data lead to the first characterization of the Tonian plutonism (Salto da Divisa Granite Suite), ascribed to the continental rift stage of the precursor basin of the Araçuaí Orogen (Eastern Brazil). The suite includes batholitic plutons and comprises mainly fluorite-bearing, dominantly mesoperthitic hornblende-biotite leucogranites. The presence of mafic (tholeiitic) gabbroic enclaves and syn-plutonic dykes confers to the suite a bimodal character. The plutons were locally deformed and foliated under amphibolite facies conditions, in response to the Neoproterozoic collage of the Araçuaí Orogen against the São Francisco Cratonic margin. However, undeformed magmatic facies are well preserved at inner portions of the plutons. The granitoids are metaluminous, with high $\mathrm{SiO}_{2}$ and $\mathrm{HFSE}$ : $\mathrm{Nb}, \mathrm{Zr}$, Y, Ta and REE (except $\mathrm{Eu}$ ); low $\mathrm{CaO}, \mathrm{Al}_{2} \mathrm{O}_{3}, \mathrm{Sc}, \mathrm{Ba}, \mathrm{Sr}$; high $\mathrm{FeOt} / \mathrm{MgO}$ ratios, characterizing a chemical signature akin to the subalkaline, A-2 type granites. U-Pb SHRIMP data obtained on zircons from the main pluton yielded a magmatic crystallization age of $875 \pm 9$ Ma. Some inherited xenocrysts revealed ages of $c a .2080 \mathrm{Ma}$, corresponding to ages of the host rocks, a Paleoproterozoic basement. Nd isotopic evolution studies confirm the Paleoproterozoic influence on magma genesis with a $\mathrm{T}_{\mathrm{DM}}$ model age of $c a .1 .6 \mathrm{Ga}$ and $\varepsilon_{\mathrm{Nd}}$ of -5.58 at $880 \mathrm{Ma}$. The African counterpart, the West Congo Belt, encompasses thick rift-related alkaline volcanic-sedimentary basin (Zadinian and Mayumbian groups, and associated anorogenic granites), dated in the interval of $c a$. 1000-900 Ma. The age differences between the Salto da Divisa Suite intrusion and the anorogenic magmatic episode at the West Congo Belt suggests a westward migration (i.e. to the Brazilian side) of the thermal axis of the rift, ca. $30 \mathrm{Ma}$ after the ending of the extensional process in Africa.
\end{abstract}

(C) 2007 International Association for Gondwana Research. Published by Elsevier B.V. All rights reserved.

Keywords: Araçuaí-West Congo orogen; Rift-related A-type granites; U-Pb SHRIMP; Tonian

\section{Introduction}

South America has prominently figured in recent reconstructions of supercontinental assemblies (eg: Rogers and Santosh, 2003; Zhao et al., 2002; da Rosa-Costa et al., 2006; Teixeira et al., 2007, and references therein). The Araçuaí Orogen occupies the northern segment of the N-S-trending Mantiqueira Province - a large and complex mosaic of Neoproterozoic/

\footnotetext{
* Corresponding author. CPRM - Serviço Geológico do Brasil - SGAN 603, Bloco J, Brasília, DF, Brazil. Tel.: +55 613223 1166; fax: +55 6132240697. E-mail address: luizcarlos@df.cprm.gov.br (L.C.da Silva).
}

Cambrian orogenic belts flanking the southeastern border of South America, from Uruguay to southern Bahia state (e.g. da Silva et al., 2005). The province was structured at $c a$. 900$500 \mathrm{Ma}$ due to the long lasting development of the BrasilianoPan African orogenic systems, culminating with the collage of the West Gondwana supercontinent at $c a$. $550 \mathrm{Ma}$ (Brito Neves et al., 1999; Brito Neves, 2002). Within this segment of Gondwana, Araçuaí and the West Congo (AWC) belts are counterparts of the same orogen, evolved in response to the collision of São Francisco and Congo cratons, presently separated by the Atlantic Ocean (Fig. 1). This evolutionary model has long been discussed and accepted on the basis of 


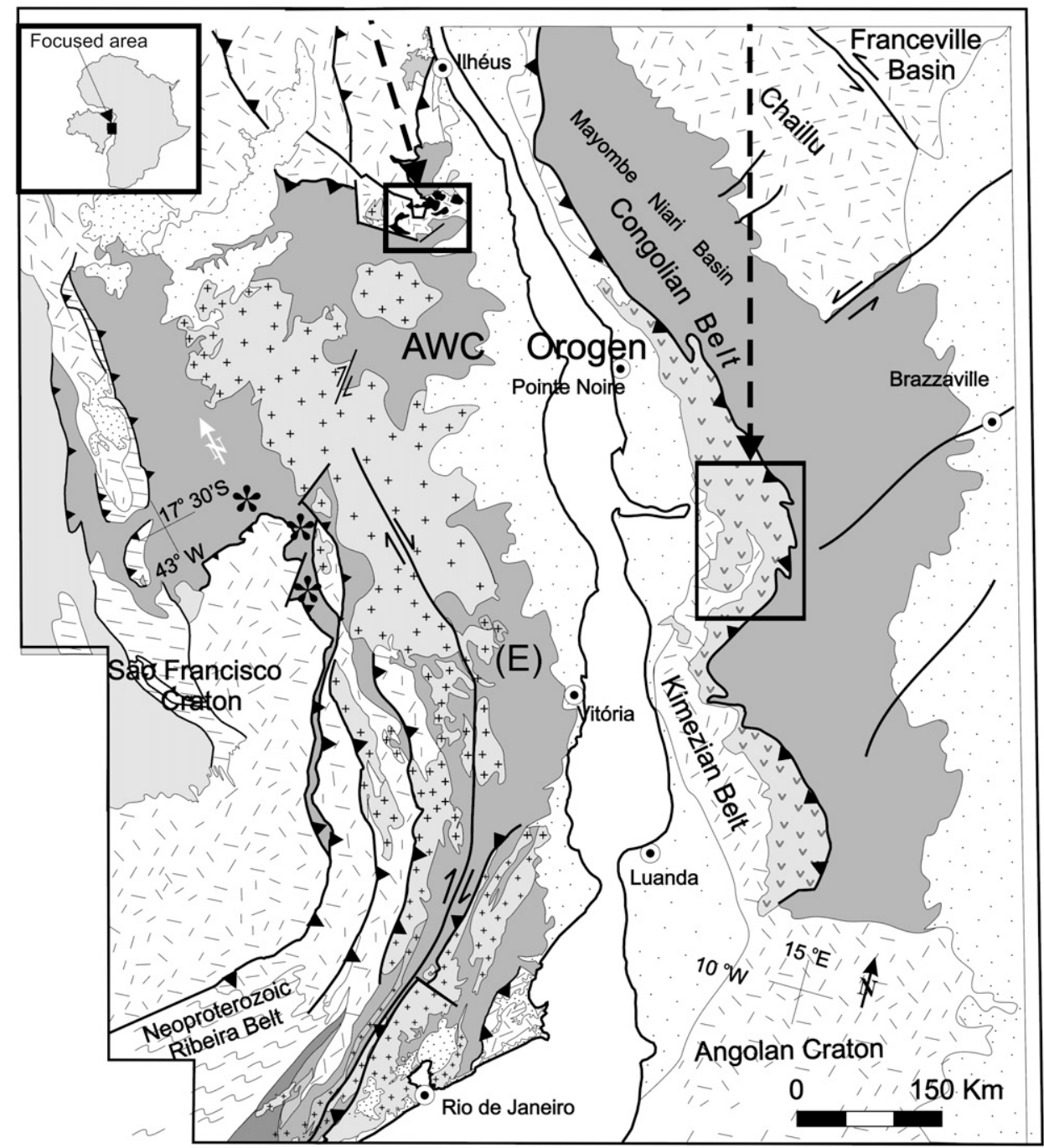

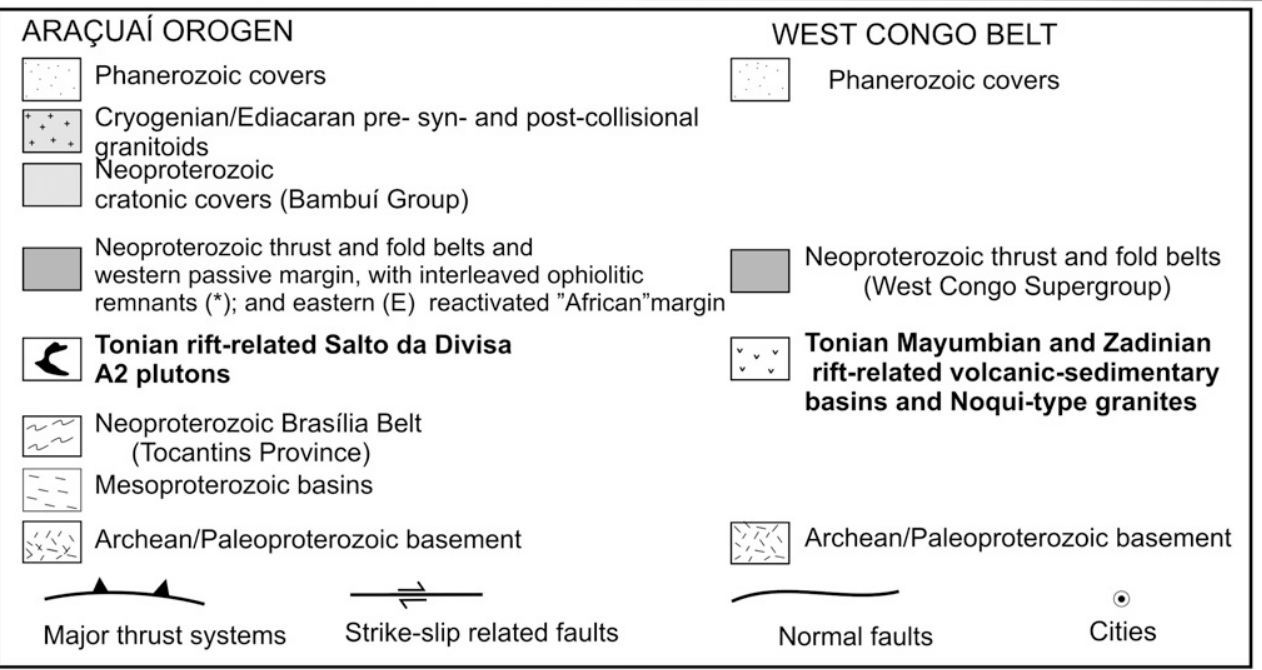

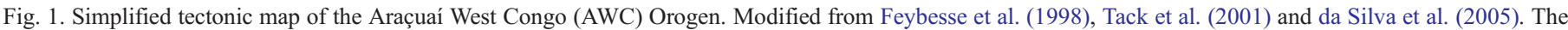

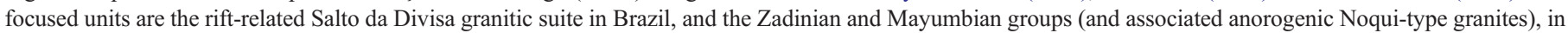
Africa.

geological and paleomagnetic data, reinforced by the complementary orogenic zoning that resulted from the late Neoproterozoic (Ediacaran) collage (e.g. D'Agrella-Filho et al., 1990;
Brito Neves and Cordani, 1991; Trompette, 1994; PedrosaSoares et al., 2001; Tack et al., 2001; Cordani et al., 2003a,b; Kröner and Cordani, 2003; D'Agrella-Filho et al., 2004; da 
Silva et al., 2005, Mantovani and Brito Neves, 2005). More recently, the AWC Orogen reconstruction was also constrained on geochronological grounds by means of several precise zircon $\mathrm{U}-\mathrm{Pb}$ SHRIMP ages ranging from $c a$. 575 to $560 \mathrm{Ma}$, obtained on the syn-collisional granitoids in Brazil (da Silva et al., 2002, 2003, 2005; da Silva, 2006). In the West Congo counterpart, there are geochronological markers from the collisional phase, radiometric data are restricted to $\operatorname{Ar}-\operatorname{Ar}$ ages (ca. $565 \mathrm{Ma}$ ), obtained from greenschist facies metabasaltic rocks (cited in Tack et al., 2001).

\section{Previous attempts of dating the precursor stage to the Araçuaí Orogen}

Previous attempts to constrain the age of the continental rift phase, precursor to the Araçuaí Orogen, were based only on indirect evidences from a glacial episode, in the range of $c a$. 1100 to $900 \mathrm{Ma}$ (Machado et al., 1989; D'Agrella-Filho et al., 1990; Buchwaldt et al., 1999; Pedrosa-Soares et al., 2000). The last mentioned authors obtained an approximate maximum depositional age of $c a .950 \mathrm{Ma}$ on detrital zircons from the glacio-marine sequence (Macaúbas Group), and speculated that the sources (of these zircons) "were magmatic rocks, perhaps sub-volcanic, formed during the rift stage of the Araçuaí-West Congo basin system" (Pedrosa-Soares et al., 2000). More recently Babinski et al. (2004) and Gradim (2005) obtained an approximate maximum age of $c a .1100 \mathrm{Ma}$ for onset of the continental rift stage by dating an inherited zircon population from metabasalts interleaved with metadiamictictes from the passive margin deposits.

We present here the characterization of a rift-related A2 (sensu Eby, 1992) subalkaline pluton (Salto da Divisa Granite Suite), situated at the NE tip of the Araçuaí Orogen (Fig. 1) (Dalton de Souza et al., 2002; Bento et al., 2002; Teixeira, 2002; Paixão and Perrella, 2004). Our focus is the pluton that gave the first direct igneous age in response to a continental breakup attempt, by means of U-Pb SHRIMP dating on zircons of $875 \pm$ $9 \mathrm{Ma}$ (da Silva et al., 2002).

\section{Constraining the age of the pre-orogenic rift-stage in the Brazilian side: the Salto da Divisa Granite Suite}

\subsection{Field data}

The Salto da Divisa Granite Suite comprises a series of multiple plutons intruded into Paleoproterozoic orthogneisses that form the northeastern basement of the Araçuaí Belt (Fig. 2). Field structural and petrographic studies as well as the geological map indicate that the plutons were deformed in a late shortening phase, characterized by foliation transposition and post-magmatic recrystallization under amphibolite facies conditions, resulting in a foliated augen gneiss (Fig. 3a and b). The deformational event is recognized as NW-trending, dextral transpressive shear zones and thrust fans, with kinematic markers defining a positive hemi-flower structure (Bento et al., 2002; Dalton de Souza et al., 2002; Martins et al., 2002). The mylonitic foliation and associated shear bands show isoclinal

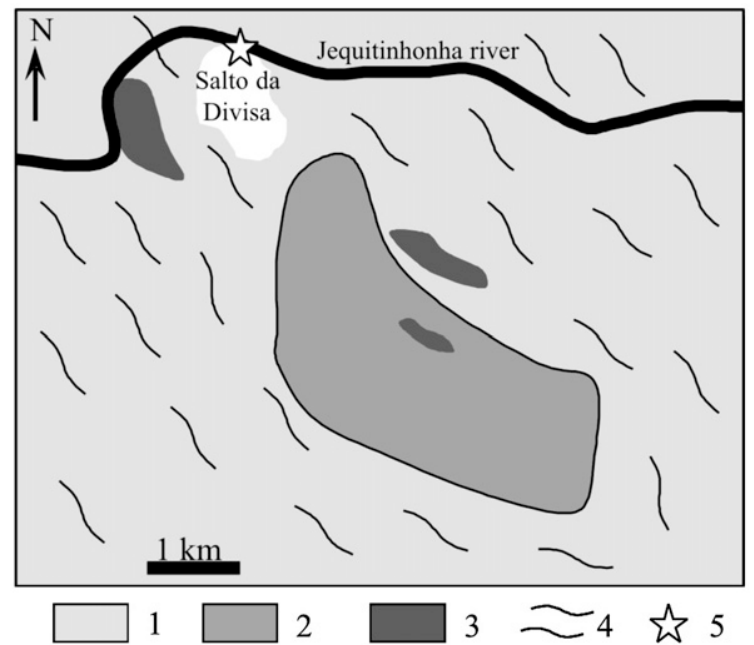

Fig. 2. Geologic map of the Salto da Divisa massif at the surroundings of the studied area. 1, foliated and mylonitic granite (orthogneiss) with enclaves and dikes of biotite amphibolite; 2 , biotite-amphibole granite without deformation; 3 , biotite-amphibole granite rich in K-feldspar phenocrysts and gabbroic enclaves; 4, NW-trending Brasiliano foliation; 5, location of the selected sample.

folding patterns and preserve sheath folds sets in the high strain domains. The overprinting episode took place at the waning stages of the Araçuaí orogen during the collision of the belt onto the eastern border of the São Francisco Craton at $c a$. 580$560 \mathrm{Ma}$, as indicated by several U-Pb SHRIMP ages performed on syn-colisional granitoids (da Silva et al., 2002, 2005).

The main pluton is flanked to southwest by amphibolite facies paragnaisses (thrust and fold belt), through prominent shear zone (Figs. 1 and 2) giving rise to the typical banded granite gneiss facies for the suite. In low strain domains contacts between the granitic plutons and the basement tonalitic orthogneiss are sharp, locally preserving angular enclaves of xenolithic nature, owing to high viscosity contrasts between the Neoproterozoic granitic phase and the Paleoproterozoic country-rock.

\subsection{Petrography}

In low strain domains the massif comprises pink, medium to coarse grained, even-grained, hypersolvus assemblages, composed by single, highly exsolved perthitic orthoclase that contains virtually no discrete plagioclase (mesoperthite-bearing facies, Fig. 3c). Subsolvus, seriate, hidiomorphic textured granites, characterized by extensive intervals of plagioclase (albite) coprecipitation with alkali feldspar under largely subsolvus conditions are also found in those domains (Fig. 3d). The main primary paragenesis is represented by orthoclase, quartz, albite, bluish-green amphibole and biotite; the last mentioned (biotite), representing a late magmatic crystallization phase. Zircon, apatite, allanite, topaz, fluorite, opaque minerals and occasional garnet are the minor accessories phases. Contents of mafic minerals are normally between $5 \%$ for the more evolved leucogranites and $15 \%$ for the less evolved facies. However, most of the exposed area of the plutons, as observed on the dated sample site, is characterized by strong post-magmatic deformation accompanied by widespread comminution and recovery of the original quartz 

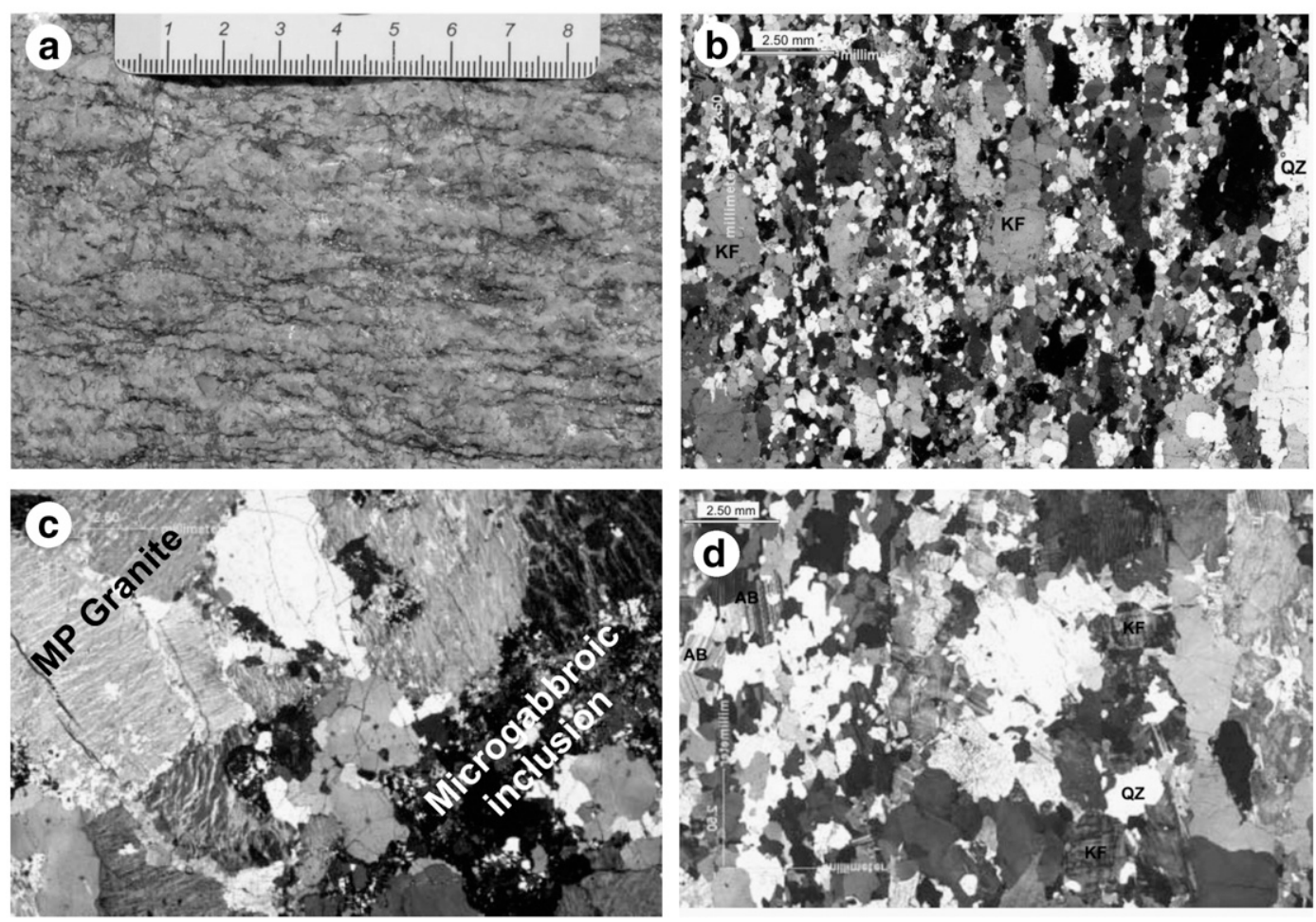

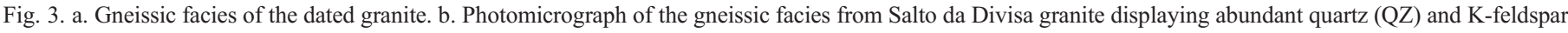

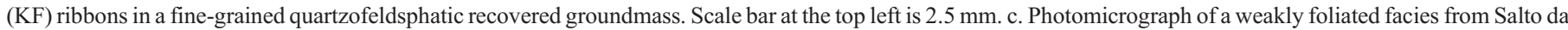

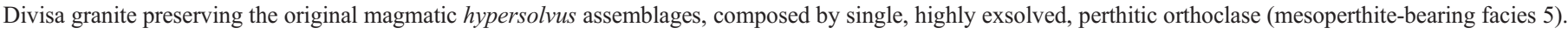

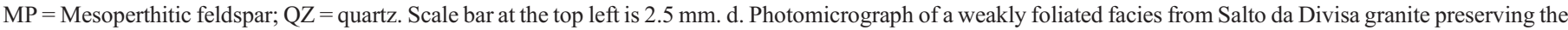

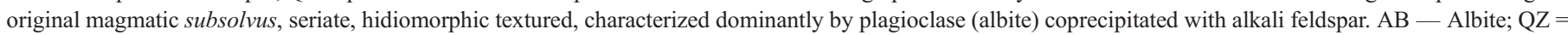
quartz; FK = alkali feldspar. Scale bar at the top left is $2.5 \mathrm{~mm}$.

and feldspars crystals, resulting in abundant fine grained, recovered (blastomylonitic) groundmass and ribbons of quartz and feldspar (Fig. 3b). Mafic minerals are also oriented parallel to the ribbons giving rise to a porfiroclastic $\mathrm{S}-\mathrm{C}$ augengneissic fabric.

Mafic plutonic enclaves are abundant but in many cases they were deformed and recrystallized in different intensities, with development of incipient to very penetrative foliation accompanied by biotitization of the amphibole and transformation of the original pyroxene to hornblende, resulting in biotite amphibolitic rocks. However, in low strain domains the original hornblende-clinopyroxene gabbroic composition is preserved. Contacts between the granite and the gabbroic enclaves are either sharp and angular, suggesting high viscosity contrasts between both magmas ("pseudo" xenoliths), or ill defined, concave-convex, showing partial assimilation of the enclaves by the surrounding granitic rock, suggesting low viscosity contrast (Fig. 3c). In more advanced stages of assimilation, intermediate rock compositions (magma mixing), are observed indicating simultaneous crystallization of the felsic and mafic components. Other evidences of this simultaneity include the presence of euhedral K-feldspar phenocrysts compositionally similar to those found in the granitic matrix within the gabbroic enclaves, as well as gabbroic veins cutting the granite (Paixão and Perrella, 2004), which are interpreted as syn-plutonic veins; both features are indicative of magma mingling processes.

\subsection{Geochemistry}

Twelve samples from two distinct facies were selected for the chemical study. Five samples are from the dominant syenogranitic to quartz monzonitic pinkish gneissic facies (Salto da Divisa), including the dated sample (labeled JM O7B in Table 1). The other seven samples came from a minor, granitic grayish facies (Itagimirim).

The chemical analyses were performed at the GEOSOL Laboratory in Belo Horizonte, Minas Gerais state, Brazil. The major elements as well as $\mathrm{Ba}, \mathrm{Sr}, \mathrm{Ta}, \mathrm{Nb}, \mathrm{Hf}, \mathrm{Zr}$, Y were analyzed by means of $\mathrm{X}$-ray equipment; $\mathrm{Cr}, \mathrm{Ni}, \mathrm{Pb}$ e $\mathrm{Zn}$, by atomic absorption; rare earth elements (REE) with ICP equipment, and $\mathrm{F}$ by specific ion electrode technique.

\subsubsection{Major, minor and rare earth elements (REE) results}

The average chemical composition is shown in Table 1. The granitoids are enriched in large highly charged cations $(\mathrm{Zr}, \mathrm{Ga}, \mathrm{Nb}$, $\mathrm{Y}$ and REE, with exception of $\mathrm{Eu}$ ), large-ion lithophile elements ( $\mathrm{K}, \mathrm{Rb}, \mathrm{LREE}, \mathrm{Th}, \mathrm{Ta}, \mathrm{Nb})$, and in $\mathrm{SiO}_{2}(>70 \%$; frequently $>73 \%)$, alkalis $\left(\mathrm{K}_{2} \mathrm{O}+\mathrm{Na}_{2} \mathrm{O}>7 \%\right)$. They also present high $\mathrm{K}_{2} \mathrm{O} /$ $\mathrm{Na}_{2} \mathrm{O}$ ratios $(>1)$ and $\mathrm{Fe} / \mathrm{Mg}$. The rocks are depleted in $\mathrm{CaO}$ 
Table 1

Major and trace element of 12 samples from Salto da Divisa Suite (Itagimirim and Salto da Divisa facies)

\begin{tabular}{|c|c|c|c|c|c|c|c|c|c|c|c|c|c|}
\hline \multirow[b]{2}{*}{ ID } & \multicolumn{7}{|c|}{ Itagimirim grayish facies } & \multicolumn{5}{|c|}{ Salto da Divisa pinkish facies } & \multirow[b]{2}{*}{ Mean } \\
\hline & VB-67 & VB-61N & VB-61E & VB-61D & VB-61H & VB-61L & VB-61C & JM-7B & VB111C & VB111D & VB112B & VB112D & \\
\hline $\mathrm{SiO}_{2}$ & 71.09 & 70.37 & 70.13 & 73.44 & 73.55 & 72.23 & 75.17 & 71.20 & 69.59 & 72.70 & 66.60 & 76.00 & 71.84 \\
\hline $\mathrm{TiO}_{2}$ & 0.53 & 0.43 & 0.24 & 0.16 & 0.26 & 0.24 & 0.13 & 0.30 & 0.39 & 0.28 & 0.48 & 0.03 & 0.29 \\
\hline $\mathrm{Al}_{2} \mathrm{O}_{3}$ & 12.38 & 13.95 & 13.12 & 12.71 & 12.59 & 11.78 & 11.02 & 13.10 & 14.20 & 12.60 & 14.80 & 12.30 & 12.88 \\
\hline $\mathrm{Fe}_{2} \mathrm{O}_{3}$ & 0.60 & 0.01 & 0.01 & 0.01 & 0.01 & 0.01 & 0.01 & 1.40 & 0.74 & 1.70 & 1.70 & 1.10 & 0.61 \\
\hline $\mathrm{FeO}$ & 5.22 & 4.29 & 6.31 & 3.80 & 4.70 & 6.52 & 4.58 & 2.80 & 3.42 & 2.10 & 3.70 & 1.10 & 4.05 \\
\hline $\mathrm{MnO}$ & 0.09 & 0.07 & 0.04 & 0.05 & 0.07 & 0.06 & 0.03 & 0.09 & 0.12 & 0.06 & 0.15 & 0.03 & 0.07 \\
\hline $\mathrm{MgO}$ & 0.26 & 0.37 & 1.18 & 0.12 & 0.01 & 0.01 & 0.10 & 0.16 & 0.22 & $<0.10$ & 0.34 & $<0.10$ & 0.28 \\
\hline $\mathrm{CaO}$ & 1.84 & 1.59 & 1.28 & 0.85 & 1.00 & 0.89 & 0.67 & 1.10 & 1.41 & 1.20 & 2.00 & 0.25 & 1.17 \\
\hline $\mathrm{Na}_{2} \mathrm{O}$ & 2.86 & 3.59 & 3.75 & 3.40 & 3.10 & 3.21 & 3.32 & 3.70 & 3.73 & 3.00 & 3.60 & 3.00 & 3.35 \\
\hline $\mathrm{K}_{2} \mathrm{O}$ & 5.01 & 5.08 & 3.75 & 5.30 & 4.60 & 4.87 & 4.97 & 5.80 & 6.14 & 5.90 & 6.08 & 5.80 & 5.28 \\
\hline $\mathrm{P}_{2} \mathrm{O}_{5}$ & 0.11 & 0.11 & 0.03 & 0.03 & 0.03 & 0.05 & 0.01 & 0.08 & 0.03 & 0.03 & 0.12 & 0.02 & 0.05 \\
\hline P.F. & 0.01 & 0.15 & 0.18 & 0.14 & 0.10 & 0.16 & 0.01 & 0.29 & 0.18 & 0.06 & 0.40 & 0.00 & 0.14 \\
\hline $\mathrm{Cr}$ & 17 & 15 & 11 & 23 & 19 & 13 & 22 & 11 & 81 & 13 & 53 & 6 & 24 \\
\hline $\mathrm{Ni}$ & 4 & 3 & 5 & 6 & 4 & 6 & 6 & 3 & 5 & 3 & 5 & 4 & 5 \\
\hline $\mathrm{Pb}$ & 22 & 25 & 15 & 28 & 23 & 22 & 31 & 11 & 5 & 21 & 11 & 29 & 20 \\
\hline $\mathrm{Zn}$ & 170 & 97 & 47 & 71 & 134 & 126 & 40 & 126 & 45 & 94 & 46 & 29 & 85 \\
\hline $\mathrm{Rb}$ & 83 & 120 & 125 & 207 & 86 & 181 & 107 & 102 & 92 & 121 & 168 & 208 & 133 \\
\hline $\mathrm{Ba}$ & 1889 & 1289 & 604 & 870 & 1220 & 1139 & 696 & 495 & 1264 & 638 & 871 & 62 & 920 \\
\hline $\mathrm{Sr}$ & 148 & 194 & 57 & 113 & 66 & 71 & 128 & 63 & 128 & 78 & 136 & 39 & 102 \\
\hline $\mathrm{Ta}$ & $<5$ & $<5$ & 7 & $<5$ & $<5$ & $<5$ & $<5$ & $<5$ & $<5$ & $<5$ & $<5$ & $<5$ & 7 \\
\hline $\mathrm{Nb}$ & 42 & 45 & 70 & 28 & 66 & 57 & 19 & 182 & 67 & 108 & 95 & 169 & 79 \\
\hline Hf & 13 & 10 & 18 & 8 & 18 & 15 & $<8$ & 19 & 12 & 15 & 25 & 11 & 15 \\
\hline $\mathrm{Zr}$ & 641 & 374 & 687 & 298 & 742 & 557 & 214 & 697 & 634 & 547 & 904 & 274 & 547 \\
\hline Y & 103 & 79 & 97 & 76 & 120 & 113 & 38 & 98 & 68 & 104 & 74 & 92 & 89 \\
\hline Th & $<5$ & $<5$ & $<5$ & 14 & 7 & $<5$ & $<5$ & 33 & 20 & 43 & 37 & 43 & 28 \\
\hline $\mathrm{La}$ & & & 23.66 & & & 67.07 & 33.92 & & 122.90 & & 129.90 & & 75.49 \\
\hline $\mathrm{Ce}$ & & & 49.02 & & & 142.10 & 64.00 & & 208.20 & & 244.10 & & 141.48 \\
\hline $\mathrm{Nd}$ & & & 21.50 & & & 58.73 & 20.96 & & 66.25 & & 88.96 & & 51.28 \\
\hline $\mathrm{Sm}$ & & & 4.87 & & & 13.24 & 3.64 & & 12.09 & & 15.38 & & 9.85 \\
\hline $\mathrm{Eu}$ & & & 0.74 & & & 1.80 & 0.67 & & 1.52 & & 2.10 & & 1.37 \\
\hline Gd & & & 4.35 & & & 10.06 & 3.01 & & 7.69 & & 10.64 & & 7.15 \\
\hline Dy & & & 3.92 & & & 7.47 & 2.17 & & 3.68 & & 7.23 & & 4.89 \\
\hline Ho & & & 0.80 & & & 1.44 & 0.48 & & 0.54 & & 1.35 & & 0.92 \\
\hline $\mathrm{Er}$ & & & 2.04 & & & 3.46 & 1.29 & & 1.13 & & 3.21 & & 2.23 \\
\hline $\mathrm{Yb}$ & & & 1.54 & & & 2.40 & 1.09 & & 0.48 & & 2.50 & & 1.60 \\
\hline $\mathrm{Lu}$ & & & 0.24 & & & 0.35 & 0.19 & & 0.06 & & 0.35 & & 0.24 \\
\hline $\mathrm{Eu} / \mathrm{Eu}^{*}$ & & & 0.482 & & & 0.46 & 0.602 & & 0.450 & & 0.477 & & 0.495 \\
\hline $\mathrm{F}$ & 980 & 1350 & 1800 & 1800 & 1450 & 2300 & 1050 & 1300 & 560 & 1600 & 1000 & 110 & 1275 \\
\hline
\end{tabular}

(frequently <1\%), $\mathrm{Al}_{2} \mathrm{O}_{3}$ (mostly <13\%), $\mathrm{MgO}$ (frequently $<0.4 \%$ ), $\mathrm{Sr}$ and $\mathrm{Ba}$. Additionaly, in response to abundance of fluorite as an accessory phase, $\mathrm{F}$ contents are high, typically $>1000 \mathrm{ppm}$. All these characteristics fall in the range of the 'A'type granite chemistry (e.g. Whalen et al., 1987; Eby, 1990, 1992).

On the multicationic R1-R2 diagram (modified from De la Roche et al., 1980), with one exception, the analyses plot in the compositional fields of "granite" and "alkaline granite" and spread along the subalkaline trend (Fig. 4). The same diagram shows the main field and the trend of the A-type granites of Whalen et al. (1987), confirming the A-type signature also suggested by the major and traces elements shown in Table 1 . $\mathrm{The} \mathrm{Fe} / \mathrm{Fe}+\mathrm{Mg} \times \mathrm{SiO}_{2}$ diagram (Frost et al., 2001) shows the high $\mathrm{Fe}$ contents of the granites and the consequent distribution of the analyses in the field of the "ferroan" granites, which characterize the anorogenic A-type granite suites (Fig. 5). Owing to the high contents of HFSE, on the $(\mathrm{Nb}+\mathrm{Y}) \times \mathrm{Rb}$ diagram of Pearce et al. (1984), all the granitoids occupy a central position in the field of the within-plate granites (WPG) (Fig. 6). On the $\mathrm{Y}-\mathrm{Nb}-\mathrm{Ce}$ triangular diagram from Eby (1992) the analyses plot dominantly in the low $\mathrm{Nb}$, high $\mathrm{Y}-\mathrm{Ce}$ field of the crustal-derived A2 granites, with only one analysis spreading across the boundaries of the fields A2/A1 (Fig. 7). The REE distribution patterns normalized to the chondritic values (Fig. 8) are moderately fractionated, with severe enrichment in the LREE ( $\mathrm{LaN}>100 \mathrm{X}$ the chondrite), accompanied by weak enrichment of the HREE ( $\mathrm{YbN} \sim 10 \mathrm{X}$ the chondrite). The HREE also show a flat distribution pattern, whereas Eu displays moderate negative anomalies (mean Eu/ $\mathrm{Eu}^{*}=0.495$ ). With exception of the lack of strong negative Eu anomalies, the overall REE signature is also characteristic of the A-type granites (Fig. 8).

On the multi-elemental diagram of Fig. 9 the normalization of the analyses to the primitive mantle values shows strong negative anomalies of $\mathrm{Sr}, \mathrm{P} \mathrm{Nb}$ and $\mathrm{Ti}$, typical of crustal derived granitic magmas, including the A2-type granitoids. 


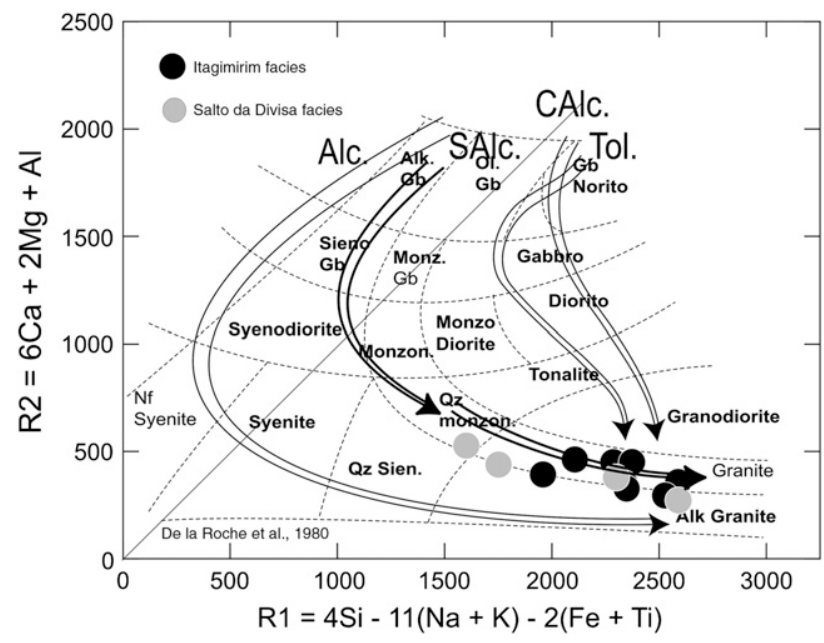

Fig. 4. R1-R2 diagram, modified from De la Roche et al. (1980) for Itagimirim facies (black circles) and for Salto da Divisa facies (grey circles).

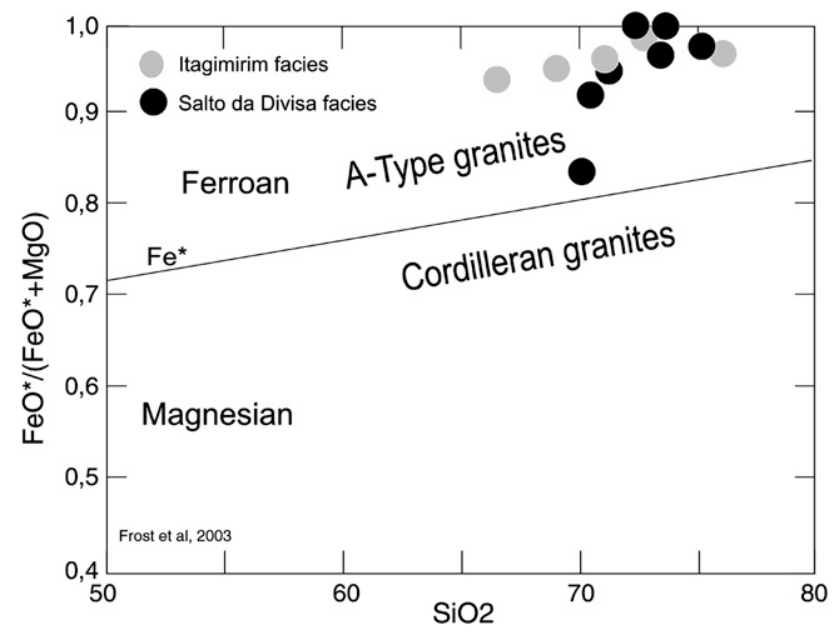

Fig. 5. Plots of $\mathrm{SiO}_{2}$ vs $\mathrm{FeO}^{*} /\left(\mathrm{FeO}^{*}+\mathrm{MgO}\right)$ (Frost et al., 2003) for Itagimirim facies (black circles) and for Salto da Divisa facies (grey circles).

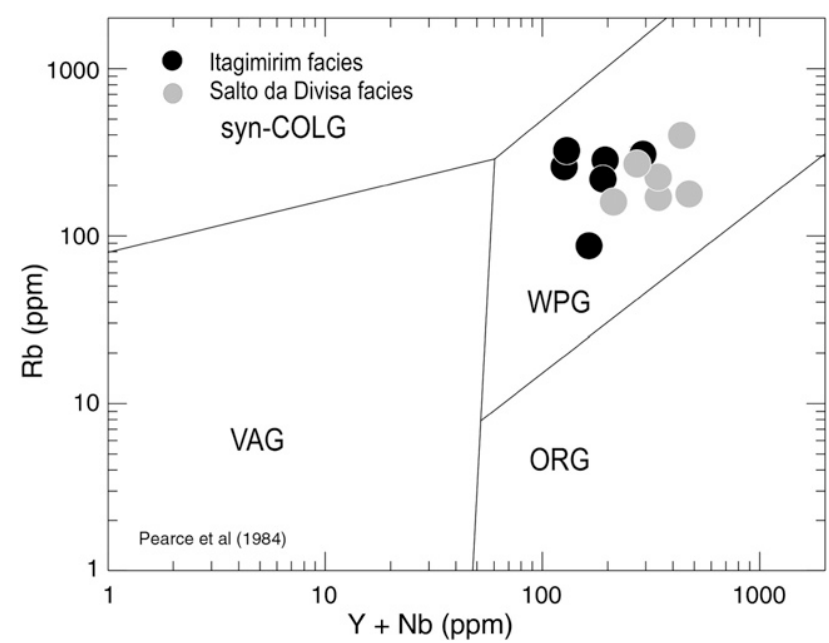

Fig. 6. Plots of $\mathrm{Y}+\mathrm{Nb}$ vs. $\mathrm{Rb}$ (Pearce et al., 1984) for Itagimirim facies (black circles) and for Salto da Divisa facies (grey circles).

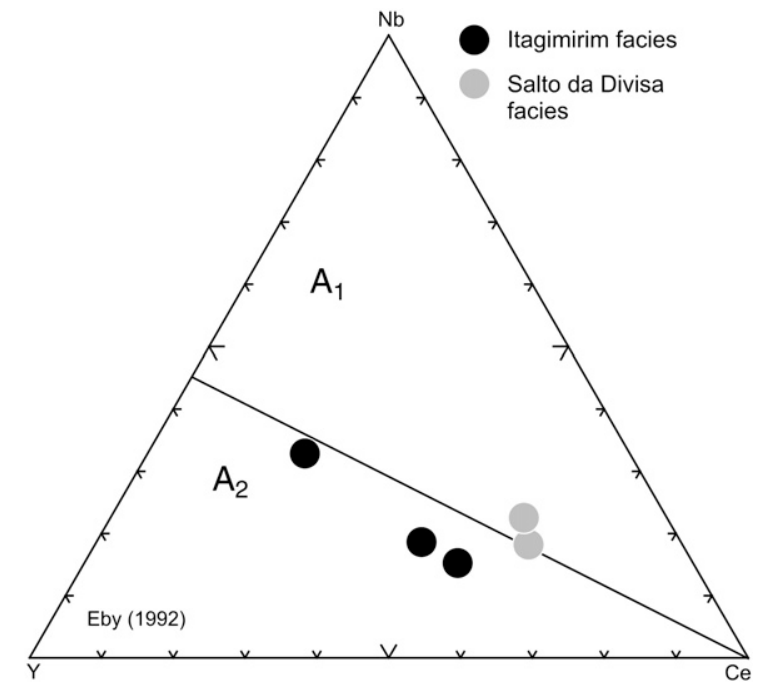

Fig. 7. Plots of Y-Ce-Nb (Eby, 2002) for Itagimirim facies (black circles) and for Salto da Divisa facies (grey circles).

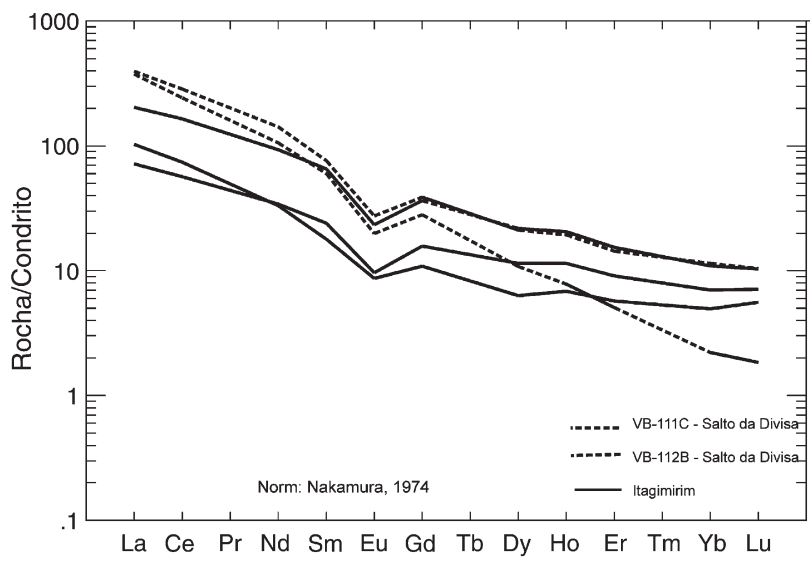

Fig. 8. Rare earth elements normalized to chondrites (Nakamura, 1974)

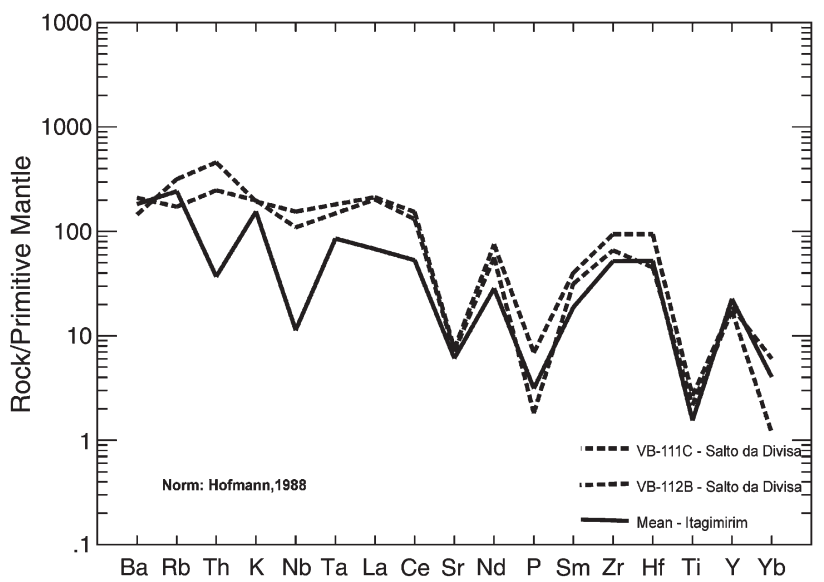

Fig. 9. Trace elements diagrams normalized to primitive mantle (Sun and McDonough, 1989). 


\subsubsection{Petrogenetic evolution}

In addition to indicating magma mingling and mixing, the presence of tholeiitic gabbroic magmas in the form of pseudo xenoliths and autholiths as well as syn-plutonic dykes, temporally and spatially associated with the granite, indicates a bimodal nature of the pluton. However, the absence of other rocks-type displaying intermediated composition between the gabbro and granite, such as tonalites and granodiorites demonstrates that the latter (granite) do not represent the felsic end member of a magmatic series. The same restriction is deduced from the scarcity of rocks with syenite, and composition less evolved than gabbros do not favoring models of fractionation of an original mafic/ultramafic (or intermediate) mantle-derived magma.

The typical A2 chemical signature indicates a (deep) crustal origin for the magma, whereas its metaluminous composition implies an orthogneissic source. Additionally, the petrographic and chemically compositional uniformity, suggests the extraction of the magma from a single and uniform orthogneissic precursor. Accordingly, fractionation processes from primary minerals should be considered the main mechanism responsible for the (slight) compositional variations, as also demonstrated for other A2 suites from northern Brazil (Dall'Agnol et al., 2005). Hypersolvus assemblages, composed by single, highly exsolved perthitic orthoclase containing virtually no discrete plagioclase (mesoperthite-bearing facies) — probably resulting from crystallization at $\mathrm{H}_{2} \mathrm{O}$-undersaturated conditions (e.g. Tuttle and Bowen, 1958), is another characteristic of this lineage of subalkaline crustal magmas. Several authors (e.g. Dall'Agnol et al., 2005) support the hypothesis that A2-type magmas were evolved in response to subcrustal mafic underplating processes, responsible for the heat increment necessary to melting and extracting the magma from lower crustal sources. The hypotheses demands anatexis operating under water-poor, halogen-rich anatectic conditions, giving rise to the final (A2-type) batch. These requirements could have been attained in the evolution of the Salto da Divisa magma through heat transfer from subcontinental underplated mantle into a chiefly Paleoproterozoic orthogneissic country rock, as deduced from the dated inherited zircons, and the $\mathrm{Nd}$ isotopes. The simultaneous intrusion of the mafic (tholeiitic) component and its mingling with the anatectic granitic magmas reinforces these interpretations.

\subsection{U-Pb SHRIMP dating}

\subsubsection{Analytical procedures}

One sample with about $15 \mathrm{~kg}$ of rock was collected from the most typical exposure of the targeted pluton. The sample was first reduced to fragments of the size of a fist and thoroughly washed in running water and dried before grinding and sieving to fractions between $0.125 \mathrm{~mm}$ and $0.065 \mathrm{~mm}$. Heavy minerals were concentrated by means of manual methods (Pan), with further separation of magnetite and ilmenite. The final heavy concentrates were processed in a Frantz Isodynamic Magnetic separator at $0.5 \mathrm{~A}$ and $10^{\circ}$ side-slope, followed by a second run at $1.0 \mathrm{~A}$ and $5^{\circ}$ side-slope. The initial sample preparation was performed at the laboratory of the Universidade Federal de Ouro
Preto, Brasil. The final preparation was performed at the laboratory of the Australia National University - ANU, in Canberra. The less magnetic fractions were examined with a binocular microscope for hand picking of zircon grains, and sorted according to distinct shape, color and transparency of populations. About 100 crystals were selected from the least magnetic zircon fraction and then cast in a standard $25-\mathrm{mm}$ epoxy mount and sectioned by polishing. The analyzed crystals were photographed under reflected and transmitted light microscope, followed by the generation of images through panchromatic light (Cathodoluminescence), at a Hitachi S$225 \mathrm{ON}$ electronic microscope, operated at $15 \mathrm{kV}$. The equipment is housed in the ANU Electron Microscopy Unit Research School of Biological Sciences. All the dated crystals had images done before the SHRIMP analyses. The mount was later lightly repolished and gold-coated for the SHRIMP microanalytical isotopic determinations. The isotopic $\mathrm{U}-\mathrm{Pb}$ analyses were obtained at the SHRIMP II equipment at The Australia National University in Canberra, Australia. Instrumental conditions and data acquisition have been described in Compston et al. (1984, 1992). The SHRIMP operation and particular procedures followed the usual routine described by Nelson (1997). The $\mathrm{Pb}, \mathrm{U}$ and $\mathrm{Th}$ concentrations were referenced to the standard zircon. One determination on the standard was obtained for each three analyses on the unknown. The spot size is typically $25 \mu \mathrm{m}$ in diameter. The age uncertainties given in the text are at the $95 \%$ confidence level for the concordant populations, and the internal precision for single analyses in the table is $1 \sigma$. The data were corrected for common $\mathrm{Pb}$ using measured ${ }^{204} \mathrm{~Pb}$ and were plotted on a TeraWasserburg concordia diagram.

\subsubsection{Cathodoluminescence imagery and zircon morphology}

The zircon morphology is very simple and is characterized by two subgroups (Fig. 10a,b). Subgroup 1 is characterized by prismatic euhedral short to isometric crystals, with low ratio aspect (length:width ratio of 2:1 and 1:1) whereas Subgroup 2 is dominated by euhedral, long-prismatic crystals (length:width ratio of $3: 1$ ), typically magmatic, but showing slightly rounding of the pyramidal terminations owing to weak metamorphic recrystallization. Zircons from both subgroups show faint magmatic growth structures (oscillatory zoning), with low U-contents (low luminescence) contrasting with two CL-dark (high-U) xenocrysts of ca. $2080 \mathrm{Ma}$ (Fig. 10a-b). The crystal with the lowest ${ }^{206} \mathrm{~Pb} /{ }^{238} \mathrm{U}$ ratio (ca. $740 \mathrm{Ma}$, in Fig. 10a) shows a thin, irregular, external, high luminescent, (metamorphic) overgrowth (spot \# 14, on Fig. 11), indicating $\mathrm{Pb} * \mathrm{f}$ loss (see explanation below).

\subsection{3. ${ }^{206} \mathrm{~Pb} /{ }^{238} \mathrm{U}$ SHRIMP age}

Seventeen analyses were obtained from 17 zircons. Results are given in Table 2 and shown in a Tera-Wasserburg concordia plot of Fig. 11. The main group of analyses $(n-9)$ clusters around concordia to give a Concordia Age of $875 \pm 8.6 \mathrm{Ma}$ (light grey error elipses). It corresponds to a homogeneous population with little excess of scatter than attributed to the analytical error $(\mathrm{MSWD}=1.2)$. This Concordia apparent age is interpreted as the crystallization age of the pluton. 

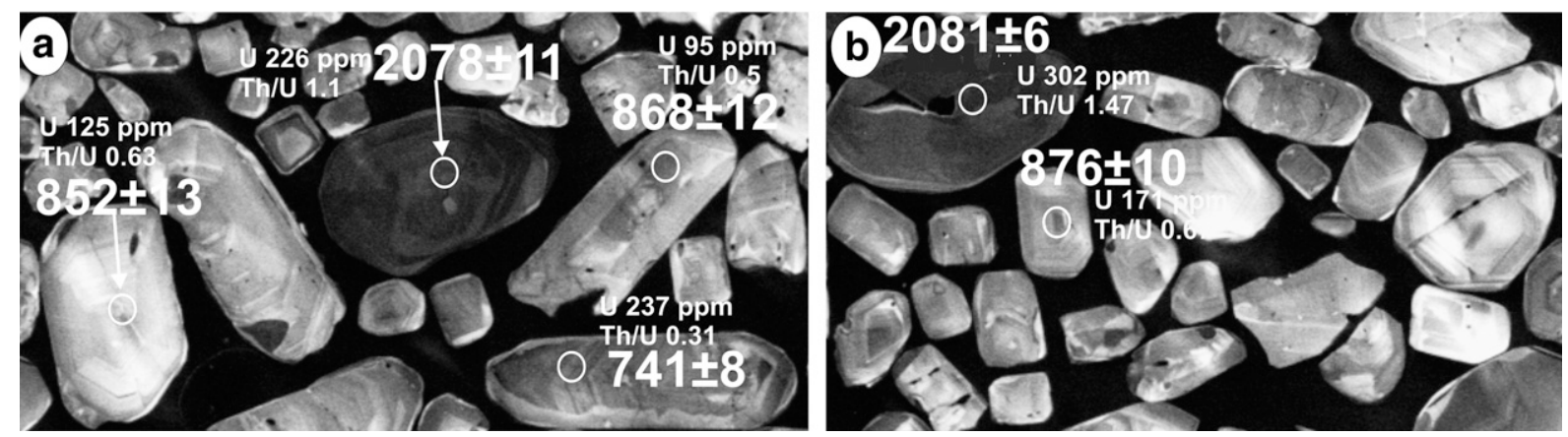

Fig. 10. a Cathodoluminescence (CL) images of zircons from sample JM 07B. b. Cathodoluminescence (CL) images of zircons from sample JM 07B.

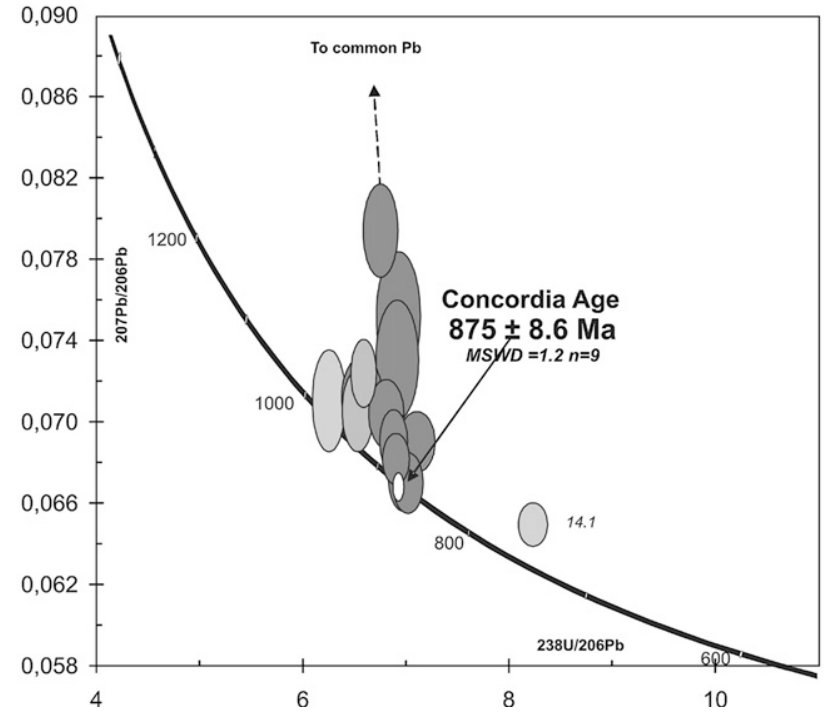

Fig. 11. Tera-Wasserburg Concordia diagram for sample JM 07B.
Five analyses do not fit in here (white error elipses): spot \# 14.1 is apparently younger $(206 * \mathrm{~Pb} / 238 \mathrm{U}$ age of $741 \mathrm{Ma})$ and interpreted to be from a crystal that has experienced a more intense $\mathrm{Pb}$-loss than the rest of the population, in response to regional deformation and metamorphic overprinting of the Araçuaí Orogen; and four analyses plot above the group hinting at some inheritance. Three others inherited crystals, yielded apparent concordant ages of $c a .2080 \mathrm{Ma}$ (Table 2; Fig. 10a,b) but are not shown on the concordia diagram of Fig. 11. This age has been repeatedly reported from the orthogneissic countryrocks intruded by the Salto da Divisa plutons. Accordingly, the inherited zircons are interpreted either as restitic material from the lower crustal gneissic source or as crystals assimilated during the ascent of magma trough the Paleoproterozoic orthogneissic country-rock.

\subsection{Sm-Nd isotopic analysis}

In order to better constrain the ages of the possible sources of the Salto da Divisa magma the dated sample was also analyzed for

Table 2

Summary of SHRIMP U-Pb zircon data for sample JM 07B (Salto da Divisa Granite) ANU-Mount Z3886

\begin{tabular}{|c|c|c|c|c|c|c|c|c|c|c|c|c|c|c|c|c|c|}
\hline $\begin{array}{l}\text { Grain- } \\
\text { spot }\end{array}$ & $\begin{array}{l}(1) \% \\
{ }^{206} \mathrm{~Pb}_{\mathrm{c}}\end{array}$ & $\begin{array}{l}\text { ppm } \\
\mathrm{U}\end{array}$ & $\begin{array}{l}\text { ppm } \\
\text { Th }\end{array}$ & $\begin{array}{l}{ }^{232} \mathrm{Th} / \\
{ }^{238} \mathrm{U}\end{array}$ & $\begin{array}{l}{ }_{206}{ }^{206} b^{*} \\
\end{array}$ & $\begin{array}{l}(1)^{207} \mathrm{~Pb}^{* /} \\
{ }^{206} \mathrm{~Pb}^{*}\end{array}$ & $\pm \%$ & $\begin{array}{l}(1)^{207} \mathrm{~Pb}^{* /} \\
{ }^{235} \mathrm{U}\end{array}$ & $\pm \%$ & $\begin{array}{l}(1)^{206} \mathrm{~Pb}^{* /} \\
{ }^{238} \mathrm{U}\end{array}$ & $\pm \%$ & $\begin{array}{l}\text { Err } \\
\text { corr }\end{array}$ & $\begin{array}{l}\text { (1) }{ }^{207} \mathrm{~Pb} / \\
\text { age }(\mathrm{Ma})\end{array}$ & ${ }^{206} \mathrm{~Pb}$ & $\begin{array}{l}\text { (1) }{ }^{206} \mathrm{~Pb} / \\
\text { age (Ma) }\end{array}$ & & $\begin{array}{l}\% \\
\text { Discordant }\end{array}$ \\
\hline $1-1$ & 0.46 & 118 & 117 & 1.02 & 14.8 & 0.0665 & 2.4 & 1.336 & 2.8 & 0.1458 & 1.3 & 0.485 & 821 & \pm 51 & 877 & \pm 11 & -7 \\
\hline $2-1$ & 0.32 & 32 & 25 & 0.8 & 3.99 & 0.0736 & 3.3 & 1.473 & 3.9 & 0.1451 & 2.1 & 0.536 & 1.032 & \pm 67 & 873 & \pm 17 & 15 \\
\hline $3-1$ & 0.36 & 89 & 63 & 0.74 & 11.7 & 0.0694 & 2.2 & 1.465 & 3.0 & 0.1531 & 2.1 & 0.683 & 912 & \pm 45 & 918 & \pm 18 & -1 \\
\hline $4-1$ & 0.16 & 118 & 103 & 0.9 & 14.6 & 0.0669 & 1.7 & 1.321 & 2.2 & 0.1432 & 1.4 & 0.621 & 834 & \pm 36 & 863 & \pm 11 & -3 \\
\hline $5-1$ & 0.86 & 34 & 23 & 0.69 & 4.25 & 0.0671 & 7.3 & 1.34 & 7.6 & 0.1444 & 2.1 & 0.281 & 840 & \pm 150 & 870 & \pm 17 & -4 \\
\hline $6-1$ & 0.36 & 95 & 25 & 0.27 & 12.1 & 0.0686 & 2.0 & 1.394 & 2.6 & 0.1474 & 1.7 & 0.631 & 887 & \pm 42 & 886 & \pm 14 & 0 \\
\hline $7-1$ & 1.03 & 56 & 52 & 0.96 & 7.24 & 0.0719 & 4.6 & 1.464 & 4.9 & 0.1477 & 1.7 & 0.345 & 983 & \pm 94 & 888 & \pm 14 & 10 \\
\hline $8-1$ & 0.09 & 301 & 428 & 1.5 & 98.1 & 0.1287 & 0.49 & 6.734 & 1.2 & 0.3793 & 1.1 & 0.914 & 2.081 & \pm 8.6 & 2.073 & \pm 20 & 0 \\
\hline $9-1$ & 0.24 & 171 & 111 & 0.67 & 21.5 & 0.0674 & 1.6 & 1.354 & 2.1 & 0.1456 & 1.2 & 0.604 & 851 & \pm 34 & 876 & \pm 10 & -3 \\
\hline $10-1$ & 0.37 & 125 & 77 & 0.63 & 15.3 & 0.0672 & 2.4 & 1.308 & 2.9 & 0.1412 & 1.6 & 0.560 & 844 & \pm 50 & 852 & \pm 13 & -1 \\
\hline $11-1$ & 0.13 & 226 & 240 & 1.1 & 72.6 & 0.1285 & 0.64 & 6.626 & 1.4 & 0.3740 & 1.2 & 0.887 & 2.078 & \pm 11 & 2.048 & \pm 21 & 1 \\
\hline $12-1$ & 0.21 & 95 & 47 & 0.51 & 11.7 & 0.0669 & 2.2 & 1.328 & 2.6 & 0.1441 & 1.5 & 0.556 & 833 & \pm 45 & 868 & \pm 12 & -4 \\
\hline $13-1$ & 0.10 & 93 & 82 & 0.92 & 11.6 & 0.0692 & 1.6 & 1.389 & 2.3 & 0.1456 & 1.6 & 0.694 & 904 & \pm 34 & 876 & \pm 13 & 3 \\
\hline $14-1$ & 0.09 & 237 & 71 & 1.3 & 24.8 & 0.0655 & 1.3 & 1.100 & 1.7 & 0.1218 & 1.2 & 0.680 & 790 & \pm 26 & 741 & \pm 8.2 & 6 \\
\hline $15-1$ & 0.00 & 46 & 45 & 1.01 & 6.37 & 0.0722 & 2.2 & 1.610 & 2.8 & 0.1617 & 1.8 & 0.625 & 992 & \pm 45 & 966 & \pm 16 & 3 \\
\hline $16-1$ & 0.38 & 71 & 51 & 0.74 & 9.39 & 0.0686 & 2.3 & 1.454 & 2.8 & 0.1538 & 1.6 & 0.563 & 886 & \pm 48 & 922 & \pm 13 & -4 \\
\hline $17-1$ & 0.43 & 108 & 51 & 0.49 & 14.3 & 0.0700 & 2.3 & 1.472 & 2.7 & 0.1525 & 1.4 & 0.514 & 928 & \pm 47 & 915 & \pm 12 & 1 \\
\hline
\end{tabular}

Errors are 1-sigma; $\mathrm{Pb}_{\mathrm{c}}$ and $\mathrm{Pb}^{*}$ indicate the common and radiogenic portions, respectively.

Error in standard calibration was $0.30 \%$ (not included in above errors but required when comparing data from different mounts). (1) Common Pb corrected using measured ${ }^{204} \mathrm{~Pb}$. 


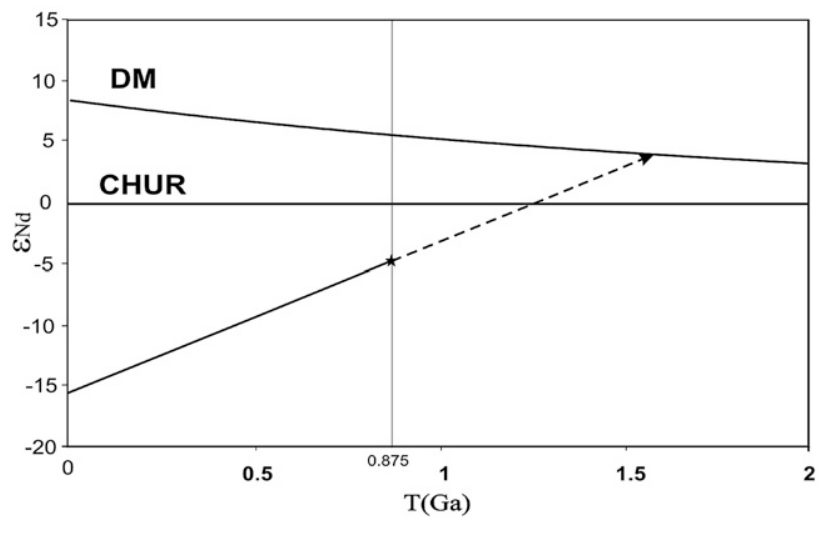

Fig. 12. Nd isotopic evolution diagram for sample JM 07B.

$\mathrm{Sm}-\mathrm{Nd}$ isotopes. The analysis was obtained at the Laboratory of Geochronology in the Instituto de Geociências, Universidade de Brasília, Brazil. The rock samples were dissolved using a mixed hydrocloric-nitric acid solution. Isotopic dilution concentration measurements of $\mathrm{Sm}$ and $\mathrm{Nd}$, and ${ }^{143} \mathrm{Sm} /{ }^{144} \mathrm{Nd}$ isotopic ratios, were determined from the sample, spiked with a mixed ${ }^{149} \mathrm{Sm}-{ }^{150} \mathrm{Nd}$ tracer. Sm and $\mathrm{Nd}$ were separated using standard ion exchange procedures and measurements were obtained using a Finnigan MAT-262 mass spectrometer. All ${ }^{143} \mathrm{Nd} /{ }^{144} \mathrm{Nd}$ isotope ratios were normalized to ${ }^{146} \mathrm{Nd} /{ }^{144} \mathrm{Nd}=0.7219$ using power law fractionation, and are relative to a BCR-1. ${ }^{143} \mathrm{Nd} /{ }^{144} \mathrm{Nd}$ isotopic ratio of 0.512680 . Errors in the $\mathrm{Sm} / \mathrm{Nd}$ ratios are less than $0.4 \%$ and $0.005 \%$ for the ${ }^{143} \mathrm{Nd} /{ }^{144} \mathrm{Nd}$. Sm and Nd procedural blanks were less than $100 \mathrm{pg}$.

\subsubsection{Sm-Nd results}

$\mathrm{Nd}$ isotopic evolution diagram for sample $\mathrm{Sm}-\mathrm{Nd}$ data yielded a moderate negative $\varepsilon_{\mathrm{Nd}}(-5.58)$ at $880 \mathrm{Ma}$, which is the $\mathrm{U}-\mathrm{Pb}$ crystallization age for the magma, and a mean crustal residence age $\left(\mathrm{T}_{\mathrm{DM}}\right.$ model age) of $c a$. $1.6 \mathrm{Ga}$ (Fig. 12). Solid lines in the diagram are extrapolations of $\mathrm{Nd}$ composition to crystallisation age; dashed line extensions to depleted mantle (DM) curve of DePaolo (1981) furnishes the $\mathrm{T}_{\mathrm{DM}}$ model age, assuming no $\mathrm{Sm} / \mathrm{Nd}$ fractionation during magma genesis (Fig. 12). In addition to the chemical signature and SHRIMP data, the $\mathrm{Nd}$ isotopes also indicate the involvement of preNeoproterozoic rocks as magma sources. However, the more accurate U-Pb SHRIMP ages of $c a$. $2080 \mathrm{Ma}$, obtained on inherited zircons cores, represent a more realistic approximation to the age of the magma source, than the $c a .1 .6 \mathrm{Ga} \mathrm{T}_{\mathrm{DM}}$ model age. Additionally, ca. $2100 \mathrm{Ma}$ is also the age of the orthogneissic country-rock of the dated pluton (da Silva et al., 2005).

\section{Tectonic consequences for the reconstructions models of the AWC Orogen}

Prior to the formation of the Brasiliano/Pan-African branched system of orogens the breakup of the southeastern southwestern African cratons gave rise to a complex interconnected system of rift basins developed between $c a$. 1000-750 Ma (e.g. Gresse et al., 2000). According to these authors, rifting apparently proceeded in the form of a series of stepped pull-apart basins that became the depositional loci for several Pan-African and sedimentary successions, developed between 800 and $750 \mathrm{Ma}$. In the West Congo Belt the riftrelated, bimodal volcano-plutonic felsic alkaline association (Mayumbian and Zadinian groups) was recently dated by means of zircon U-Pb SHRIMP technique and furnished crystallization ages between $c a$. $1000 \mathrm{Ma}$ and $910 \mathrm{Ma}$, including the peralkaline Noqui Granite intrusion (Tack et al., 2001). During this extended time interval of $100 \mathrm{Ma}$ the infilling of a thick ( $c a$. $8000 \mathrm{~m}$ height) rift-related volcanic-sedimentary basin took place (Tack et al., 2001). This rifting episode corresponded to a major, but unsuccessful attempt to break up and rifting the central sector of the São Francisco-Congo paleocontinent. However, the effective fragmentation of the continent took place farther southwest, roughly along the present-day axis of the Araçuaí Orogen, culminating with the spreading of the Ribeirão da Folha oceanic arm at ca. $820 \mathrm{Ma}$ (Pedrosa-Soares et al., 1998, 2001).

The age differences between the intrusion of the Salto da Divisa granite ( $c a .880 \mathrm{Ma}$ ) and the outpouring of the alkaline lavas and granitoids intrusion of the Zadinian and Mayumbiam groups, from $c a$. 1000-910 Ma, suggest a westward migration of the thermal axis of the rift to the Brazilian side, some $30 \mathrm{Ma}$ after the end of the of the rifting process in Africa. Additionally, the prominent thickness of the volcanic bimodal pile in the West Congo Belt, compared to the scarce occurrences of rift-related magmatism in the Araçuaí Orogen, suggests that the rift was asymmetric, with the thermal axis located at the African side.

Despite the lack of reliable radiometric ages $(\mathrm{U}-\mathrm{Pb})$ for the collisional stage in Africa, comparison of the orogenic events in both belts also favors an integrated evolution from break up to collision (the AWC Orogen), as shown in the reconstruction model depicted in Fig. 1. In Brazil, the collisional stage was precisely bracketed between ca. 575 to $560 \mathrm{Ma}$, by means of U$\mathrm{Pb}$ ages obtained from several syn-collisional plutons (da Silva et al., 2002, 2005). Similar results, based on Ar-Ar data from metabasalts, also point to ages of ca. $565 \mathrm{Ma}$ for the metamorphic peak in Congo (Tack et al., 2001). After the Atlantic Ocean opening in Mesozoic times, the western branch (Araçuaí) inherited two thirds of the orogenic belt, including: $i$ ) the western continental margin deposits; ii) the entire precollisional magmatic arc: iii) most, if not the entire syncollisional metamorphic-anatectic core; $i v$ ) the western border of the Bas-Congo passive margin deposits, which became the loci of an active margin, owing to the incorporation of the magmatic arc (and associated back arc basin) and; iv) the suture zone, characterized by several dismembered ophiolitic remnants.

\section{Acknowledgments}

The authors are grateful to the reviewers Benjamin Bley de Brito Neves and William Randall Van Schmus and to the guesteditor Renata Schmitt for their suggestions, which led to great improvement of the original manuscript. 


\section{References}

Babinski, M., Gradim, R.J., Alkmim, F.F., Pedrosa-Soares, A.C., Liu, D., 2004. Geocronologia U-Pb (SHRIMP) em zircões de metamáficas do vale do rio Preto, faixa Araçuaí, MG. Congresso Brasileiro de Geologia, $43^{\circ}$, vol. S7. Sociedade Brasileira de Geologia, Araxá, Anais, p. T867 (1 CD-ROM).

Bento, R.V., Santos, R.A., Dalton de Souza, J., 2002. Análise estrutural cinemática do segmento nordeste da Faixa Araçuaí, extremo sul da Bahia. Congresso Brasileiro de Geologia, $42^{\circ}$. Sociedade Brasileira de Geologia, João Pessoa, p. 342. Anais (1 CD-ROM).

Brito Neves, B.B., Cordani, U., 1991. Tectonic evolution of South America during the Late Proterozoic. Precambrian Research 53, 23-40.

Brito Neves, B.B., 2002. Main stages of the development of the sedimentary basins of South America and their relationship with the tectonics of supercontinents. Gondwana Research 175-196.

Brito Neves, B.B., Campos Neto, M.C., Fuck, R.A., 1999. From Rodinia to Western Gondwana: an approach to the Brasiliano-Pan African Cycle and orogenic collage. Episodes 22, 155-166.

Buchwaldt, R., Toulkeridis, T., Babinski, M., Santos, R., Noce, C.M., MartinsNeto, M., Hercos, C.M., 1999. Age determination and age related provenance analysis of the Proterozoic glaciation event in central-eastern Brazil. Servicio Geologico Minero Argentine. South American Symposium on Isotope Geology, 2. Actas, Cordoba, pp. 387-390.

Compston, W., Williams, I.S., Meyer, C., 1984. Geochronology of zircons from the lunar breccia 73,217 using a sensitive high mass resolution ion microprobe. Journal of Geophysical Research 89 (Supp. B), 525-534.

Compston, W., Williams, I.S., Kirschvink, J.L., Zichao, Z., Guogan, M., 1992. Zircon ages for the Early Cambrian time-scale. Journal of the Geological Society (London) 149, 171-184.

Cordani, U.G., Brito Neves, B.B., D’Agrella-Filho, M.S, 2003a. From Rodinia to Gondwana: a review of the available evidence from South America. Gondwana Research 6, 275-283.

Cordani, U.G., Brito Neves, B.B., D’Agrella, M.S., Trindade, R., 2003 b. Tearing-up Rodinia: the Neoproterozoic paleogeography of South American cratonic fragments. Terra Nova 15, 343-349.

D’Agrella-Filho, M.S., Pacca, I.G., Teixeira, W., Onstott, T.C., Renne, P.R., 1990. Paleomagnetic evidence for the evolution of Meso- to Neoproterozoic glaciogenic rocks in central-eastern Brazil. Palaeogeography, Palaeoclimatology, Palaeoecology 80, 255-265.

D'Agrella-Filho, M.S., Pacca, I.I.G., Trindade, R.I.F., Teixeira, W., Raposo, M.I.B., Onstott, T.C., 2004. Paleomagnetism and ${ }^{40} \mathrm{Ar}^{39} \mathrm{Ar}$ ages of mafic dykes from Salvador (Brazil): new constraints on the São Francisco Craton APW path between 1080 and 1010 Ma. Precambrian Research $132,55-77$.

Dall'Agnol, R., Teixeira, N.P., Rämo, O.T., Moura, C.A.V, Macambira, M.J.B., Oliveira, D.C., 2005. Petrogenesis of the Paleoproterozoic rapakivi A-type granites of the Archean Carajás metallogenic province, Brazil. Lithos 80, $101-109$.

Dalton de Souza, J., Santos, R.A., Bento, R.V., 2002. Estrutura em Hemiflor Positiva no Maciço Granítico de Salto da Divisa (MG): uma Intrusão Neoproterozóica Precoce da Faixa Araçuaí. In: Congresso Brasileiro de Geologia, $42^{\circ}$, Sociedade Brasileira de Geologia. João Pessoa, Anais, p. 342, (1 CD-ROM).

De la Roche, H., Leterrier, J., Grande Claude, P., Marchal, M., 1980. A classification of volcanic and plutonic rocks using R1-R2 diagrams and major element analyses - its relationships and current nomenclature. Chemical Geology 29, 183-210.

DePaolo, D.J., 1981. A neodymium and strontium isotopic studyof the Mesozoic calcalkaline granitic batholiths of the Sierra Nevada and Peninsular Ranges, California. Journal of Geophysics Research 86, 10470-10488.

Eby, G.N., 1990. The A-type granitoids: a review of their occurrence and chemical characteristics and speculations on their petrogenesis. Lithos 26, 115-135.

Eby, G.N., 1992. Chemical subdivision of the A-type granitoids: petrogenetic and tectonic implications. Geology 20, 641-644.

Feybesse, J.L., Johan, V., Triboulet, C., Guerrot, C., Mayaga Mikolo, F., Bouchot, V., Eko N'dong, J., 1998. The West Central African Belt, a model of 2.5-2.0 Ga accretion and two-phase orogenic evolution. Precambrian Research 87 (3/4), 161-216.

Frost, B.R., Barnes, C.G., Collins, W.J., Arculus, R.J., Ellis, D.J., Frost, C.D., 2001 A geochemical classification for Granitic Rocks. Journal of Petrology 42, 2033-2048.

Gradim, R.J., 2005. Geologia estrutural e significado tectônico dos xistos verdes do Alto Araçuaí, Faixa Araçuaí. MG. Contribuições às Ciências da Terra, vol. 22. Universidade Federal de Ouro Preto, Ouro Preto, Brazil. 117 pp.

Gresse, P.G., da Silva, L.C., Germs, G.J.B., Hartmann, L.A., 2000. Neoproterozoic evolution of Southwestern Gondwana. 31st International Geological Congress. Abstracts, Rio de Janeiro. 1CD.

Kröner, A., Cordani, U., 2003. African, southern Indian and South American cratons were not part of the Rodinia supercontinent: evidence from field relationships and geochronology. Tectonophysics 375, 325-352.

Machado, N., Schrank, A., Abreu, F.R., Knauer, L.G., Abreu, P.A.A., 1989 Resultados preliminares da geocronologia $\mathrm{U}-\mathrm{Pb}$ na serra do Espinhaço Meridional: Boletim da Sociedade Brasileira de Geologia. Geol., Núcleo MG, vol. 10, pp. 171-174.

Mantovani, M.S.M., Brito Neves, B.B., 2005. The Paranapanema Lithospheric Block: its importance for Proterozoic (Rodinia, Gondwana) Supercontinent Theories. Gondwana Research 8, 303-315.

Martins, A.A.M., Loureiro, H.S.C., Arcanjo, J.B., Moraes Fo., J.C.R., Kosin, M., Bento, R.V., Borges, V.P., 2002. Projeto Extremo Sul. Mapa Geológico e de Recursos Minerais, Escala 1:200.000. Salvador. Serviço Geológico do Brasil/ CPRM.

Nelson, D.R., 1997. Compilation of SHRIMP U-Pb zircon geochronology data, 1996. Geological Survey of Western Australia, Record, vol. 1997/2, p. 189

Nakamura, N., 1974. Determination of REE, Ba, Fe, Mg, Na, and $\mathrm{K}$ in carbonaceous and ordinary chondrites. Geochimica et Cosmochimica Acta 38, 757-775.

Paixão, M.M., Perrella, P., 2004. Mapeamento geológico da área do contato entre o Maciço Granítico Salto da Divisa e o Complexo Jequitinhonha, Nordeste de Minas Gerais. Trabalho Geológico de Graduação, monography, Universidade Federal de Minas Gerais. Departamento de Geologia, Belo Horizonte, Brasil. 196 pp.

Pearce, J.A., Harris, N.B.W., Tindle, A.G., 1984. Trace element discrimination diagrams for the tectonic interpretation of granitic rocks. Journal of Petrology 25, 956-983.

Pedrosa-Soares, A.C., Vidal, F., Leonardos, O.H., Brito Neves, B.B., 1998 Neoproterozoic oceanic remnants in eastern Brazil: further evidence and refutation of an exclusively ensialic evolution for the Araçuaí-West Congo Orogen. Geology 26, 519-522.

Pedrosa-Soares, A.C., Cordani, U.G., Nutman, A., 2000. Constraining the age of Neoproterozoic glaciation in eastern Brazil: first U-Pb (SHRIMP) data of detrital zircons. Revista Brasileira de Geociências 30, 58-61.

Pedrosa-Soares, A.C., Noce, C.M., Wiedemann, C.M., Pinto, C.P., 2001. The Araçuaí-West-Congo Orogen in Brazil: an overview of a confined orogen formed during Gondwanaland assembly. Precambrian Research 110, 307-323.

Rogers, J.J.W., Santosh, M., 2003. Supercontinents in Earth History. Gondwana Research 6, 357-368.

da Rosa-Costa, L.T., Lafon, J.M., Delor, C., 2006. Zircon geochronology and $\mathrm{Sm}-\mathrm{Nd}$ isotopic study: Further constraints for the Archean and Paleoproterozoic geodynamical evolution of the southeastern Guiana Shield, north of Amazonian Craton, Brazil. Gondwana Research 10, 277-300.

da Silva, Luiz Carlos, 2006. Geocronologia aplicada ao mapeamento regional, com ênfase na técnica U-Pb SHRIMP e ilustrada com estudos de casos brasileiros. Brasília: CPRM, 132 p. (Publicações Especiais do Serviço Geológico do Brasil; n.1). Available on: $<$ www.cprm.gov.br $>$.

da Silva, L.C., Armstrong, R., Noce, C.M., Carneiro, M.A., Pimentel, M.M., Pedrosa-Soares, A.C., Leite, C.A., Vieira, V.S., Silva, M.A., Paes, V.J.C., Cardoso Filho, J.M., 2002. Reavaliação da evolução geológica em terrenos pré-cambrianos brasileiros, com base em novos dados U-Pb SHRIMP, Parte II: Orógeno Araçuaí, Cinturão Mineiro e Cráton São Francisco Meridional. Revista Brasileira de Geociências 32, 513-528.

da Silva, L.C., McNaughton, N.J., Hartmann, L.A., Fletcher, I., 2003. Zircon U-Pb SHRIMP dating of the Serra dos Órgãos and Rio de Janeiro granitic suites: implications for the (560 Ma) Brasiliano/Pan-African collage. Revista Brasileira de Geociências 33, 237-244. 
da Silva, L.C., McNaughton, N.J., Armstrong, R., Hartmann, L.A.I., 2005. The Neoproterozoic Mantiqueira Province and its African connections: a zirconbased $\mathrm{U}-\mathrm{Pb}$ geochronologic subdivision for the Brasiliano/Pan-African systems of orogens. Precambrian Research 136, 203-240.

Sun, S.S., McDonough, W.F., 1989. Chemical and isotopic systematics of oceanic basalts: implications for mantle composition and processes. In: Saunders, A.D., Norry, M.J. (Eds.), Magmatism in Ocean Basins. Geological Society of London Special Publication, vol. 42, pp. 3131-3345.

Tack, L., Wingate, M.T.D., Liégeos, J.P., Fernandes Alonso, M., Deblond, A., 2001. Early Neoproterozoic magmatism (100-900 Ma) of the Zadinian and Mayumbian goups (Bas Congo): onset of the Rodinia rifting at the west edge of Congo Craton. Precambrian Research 110, 277-306.

Teixeira, L.R., 2002. Relatório Temático de Litogeoquímica - Projeto Extremo Sul da Bahia. Convênio Serviço Geológico do Brasil, CPRM/CBPM. Salvador, $27 \mathrm{pp}$.
Teixeira, J.B.G., Misi, A., da Silva, M.G., 2007. Supercontinent evolution and the Proterozoic metallogeny of South America. Gondwana Research 11, 346-361.

Trompette, R., 1994. Geology of Western Gondwana (2000-500 Ma). Balkema, Amsterdam. 350 pp.

Tuttle, O.F., Bowen, N.L., 1958. Origin of granite in the light of experimental studies in the system $\mathrm{NaAlSi}_{3} \mathrm{O}_{8}-\mathrm{KAlSi}_{3} \mathrm{O}_{8}-\mathrm{SiO}_{2}-\mathrm{H}_{2} \mathrm{O}$. Memoir Geological Society of America 74, 153.

Whalen, J.B., Currie, K.L., Chappell, B.W., 1987. A-type granites: geochemical characteristics, discrimination and petrogenesis. Contributions to Mineralogy and Petrology 95, 407-419.

Zhao, G., Sun, M., Wilde, S.A., 2002. Did South America and West Africa marry and divorce or was it a long-lasting relationship? Gondwana Research 5, 591-596. 